\title{
MORPHOMETRIC AND GROWTH PATTERNS OF THE BLOOD CLAM (Anadara granosa) FROM THE BAGAN SIAPI-API COASTAL AREA ROKAN HILIR
}

\section{MORFOMETRIK DAN POLA PERTUMBUHAN KERANG DARAH (Anadara granosa) DI PERAIRAN BAGAN SIAPI-API KABUPATEN ROKAN HILIR}

\author{
Silfia Eka Dewi ${ }^{1}$, Eddiwan $^{2}$, Efawani $^{2}$ \\ ${ }^{1}$ Kekhususan Manajemen Sumberdaya Perairan, Fakultas Perikanan dan Kelautan, Universitas \\ Riau, JL. HR Soebrantas Km 12,5 Simpang Baru, Panam-Pekanbaru Indonesia 28293 \\ Correspondence Author: silfia.eka@student.unri.ac.id
}

\begin{tabular}{|c|c|}
\hline I N F O A R T I K E L & A B S T R A C T \\
\hline $\begin{array}{l}\text { Diterima: } 10 \text { Agustus } 2018 \\
\text { Disetujui: } 20 \text { Oktober } 2018\end{array}$ & This study was conducted in the intertidal zone in the waters of Bagan \\
\hline $\begin{array}{l}\text { Kata kunci: } \\
\text { Kerang Darah, } \\
\text { Morfologi, } \\
\text { Karakter Meristik, } \\
\text { Alometrik Negatif }\end{array}$ & $\begin{array}{l}\text { examine morphometrics and growth patterns in blood clams (Anadara } \\
\text { granosa) in Bagan Siapi-api waters. A total of } 100 \text { samples }(23.89-50.52 \\
\text { mm shell length and } 3.85-18.16 \text { grams total weight) were analyzed. From } \\
\text { the results of observations it was found that the number of male and female } \\
\text { ribs was } 8-20 \text {, and there were } 3 \text { differences in morphometric characteristics } \\
\text { between male and female, namely male blood clams longer than females, } \\
\text { while female blood shells were wider and thicker than males. Furthermore, } \\
\text { the growth pattern of } A \text {. granosa was negative allometric, with male b } \\
\text { values } 1.46 \text { and females } 0.74 \text {. }\end{array}$ \\
\hline
\end{tabular}

\section{PENDAHULUAN}

Kerang darah atau Anadara granosa merupakan salah satu jenis biota laut yang termasuk filum moluska dari kelas gastropoda yang memiliki peranan penting bagi lingkungan perairan. Kerang darah banyak ditemukan pada substrat yang berlumpur. Ciri-ciri dari kerang darah adalah mempunyai dua keping cangkang yang tebal, elips dan kedua sisi sama. Cangkang berwarna putih ditutupi periostrakum yang berwarna kuning kecokelatan sampai cokelat kehitaman (Latifah, 2011).

Kerang dara banyak di jumpai di perairan Bagan Siapi-api Kabupaten Rokan Hilir. Di kawasan ini pula nelayan sering melakukan pengambilang kerang darah secara terus menerus. Kerang darah banyak dimanfaatkan oleh masyarakat untuk kebutuhan konsumsi atau untuk dijual. Pengambilan kerang darah yang dilakukan oleh nelayan tidak mengenal ukuran atau pengambilannya tidak dilakukan secara selektif. Semua ukuran yang ditangkap diambil dari ukuran yang terkecil sampai yang terbesar. Permintaan yang terus meningkat dikhawatirkan akan menyebabkan terjadinya over eksploitasi. Terlebih lagi aktivitas perkapalan yang berlalu lintas di perairan tersebut akan menimbulkan getaran-getaran pada perairan tersebut dan mengganggu substrat dasar perairan sehingga menambah tekanan terhadap keberadaan kerang ini. Tekanan tersebut diduga dapat mempengaruhi pola pertumbuhan kerang darah. Berdasarkan uraian di atas, dirasa perlu untuk dilakukan penelitian mengenai morfometrik dan pola 
pertumbuhan kerang darah di perairan Bagan siapi-api Kabupaten Rokan Hilir yang hingga saat ini masih terbatas.

\section{METODE PENELITIAN}

Penelitian ini dilaksanakan pada Mei-Juni 2018, bertempat di perairan pantai Bagan Siapi-api Kecamatan Bangko Kabupaten Rokan Hilir. Metode yang digunakan dalam penelitian ini adalah metode survei, dimana perairan Bagan Siapi-api dijadikan lokasi survei dan kerang darah dijadikan objek penelitian. Karakteristik habitat yang dicatat adalah suhu, kecerahan, pH, oksigen terlarut dan tipe substrat.

\section{Pengambilan Sampel}

Pengambilan sampel kerang darah pada tiap titik sampling menggunakan hand collecting, dan dikoleksi secara acak sederhana (simple random sampling). Koleksi sampel dilakukan ketika terjadi surut. Sampel dikoleksi sekali dalam seminggu, selama satu bulan. Jumlah sampel yang dikoleksi keseluruhan nya adalah 762 individu. Sampel yang diukur sebanyak 100 individu. Untuk identifikasi sampel dan penghitungan morfometriknya dilakukan di Laboratorium Biologi Perairan Fakultas Perikanan dan Kelautan, dengan acuan Dharma (2005) "Recent and Fossil Indonesian Shells" dan Capenter dan Niem (1998) "The Living Marine Resource of the Western Central Pacific Vol. 1. Seaweeds, Corals, Bivalves and Gastropods".

\section{Pengukuran Morfometrik Kerang Darah}

Pengukuran morfometrik kerang darah ini dilakukan dengan menggunakan alat kaliper atau jangka sorong dengan ketelitian $0,01 \mathrm{~mm}$. Kerang darah yang telah diukur morfometriknya, lalu ditimbang berat total (BT). Pengukuran berat total dilakukan dengan menggunakan timbangan digital dengan ketelitian 0,01 g. Berat total (BT) kerang diukur dengan cara menimbang kerang secara keseluruhan beserta cangkangnya. Adapun ketentuan dalam pengukuran morfometrik kerang darah ini dapat dilihat pada Gambar 1 dan Tabel 1.

\section{Karakteristik Habitat Kerang darah \\ 1. Fraksi Sedimen}

Sampel substrat dari pantai diambil sebanyak 25 gram dan dikeringkan dalam oven dengan suhu $60-70{ }^{\circ} \mathrm{C}$ selama 24 jam. Selanjutnya substrat diletakkan ke dalam beaker glass yang berisi $250 \mathrm{ml}$ air kran dan ditambahkan hydrogen peroksida, kemudian diaduk selama 1015 menit dengan tangkai mekanis. Suspensi substrat disaring menggunakan saringan dengan ukuran 2,0,5;0,25;0,063 mm dengan menyemprotkan air kran ke saringan sehingga partikel yang berukuran lebih kecil lolos dari mata saringan dan yang berukuran besar akan tertahan. Setiap fraksi yang tertahan dikeringkan pada masing-masing saringan dengan suhu $100{ }^{\circ} \mathrm{C}$ selama 4 jam. Setelah kering kemudian ditimbang beratnya untuk mengetahui persentase berat dari masing-masing fraksi (Buchanan, 1984).

\section{Parameter Fisika dan Kimia Perairan}

Parameter perairan yang diukur adalah suhu, kecerahan, salinitas, derajat keasaman $(\mathrm{pH})$ dan oksigen terlarut. Pengukuran parameter perairan dilakukan saat pasang air laut.

\section{Analisis Data}

Keseluruhan data yang diperoleh dari hasil penelitian ini ditabulasikan dan digambarkan dalam bentuk grafik, selanjutnya dianalisis secara deskriptif.

Gambar 1. Karakter Morfometrik Kerang Dara (A.granosa) (Sari, 2010)
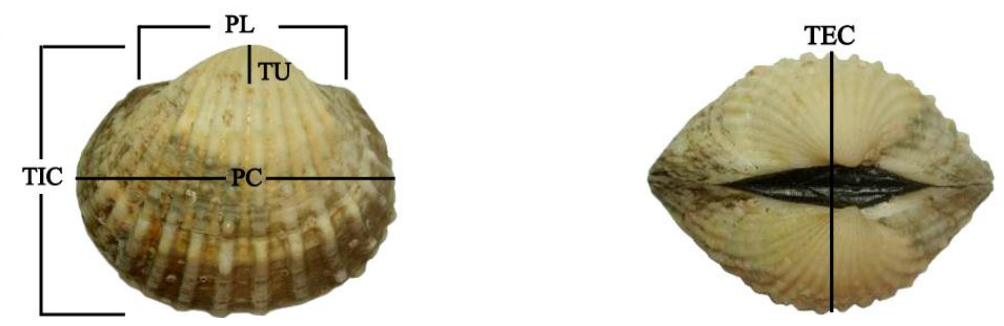
Tabel 1. Karakter Morfometrik yang Diukur

\begin{tabular}{|c|c|c|}
\hline No. & \multicolumn{2}{|c|}{ Karakter Morfometrik } \\
\hline 1 & Panjang Cangkang (PC) & $\begin{array}{l}\text { Jarak dari bagian anterior sampai bagian } \\
\text { posterior kerang. }\end{array}$ \\
\hline 2 & Tinggi Cangkang (TIC) & $\begin{array}{l}\text { Jarak dari bagian dorsal yaitu pada bagian } \\
\text { umbo sampai bagian ventral. }\end{array}$ \\
\hline 3 & Panjang Ligament (PL) & $\begin{array}{l}\text { Jarak terjauh antara cangkang kanan dan } \\
\text { cangkang kiri. }\end{array}$ \\
\hline 4 & Tinggi Umbo (TU) & $\begin{array}{l}\text { Tinggi cangkang dikurangi dengan tinggi } \\
\text { dari ventral sampai ligament. }\end{array}$ \\
\hline 5 & Tebal Cangkang (TEC) & $\begin{array}{l}\text { Jarak titik tertinggi dari cangkang kanan dan } \\
\text { cangkang kiri. }\end{array}$ \\
\hline
\end{tabular}

\section{Deskripsi Kerang Darah}

Kerang darah yang ditemukan di lokasi penelitian ini mempunyai karakteristik antara lain adalah: Cangkang berukuran sedang sampai besar, cangkang tebal dan berat, lebih menebal di bagian ventral, cangkang tidak berbulu, bentuk oval menggembung, umbo sangat menonjol, memiliki garis rusuk sekitar 18-22, ditutupi periostrakum berwarna cokelat kekuningan sampai cokelat kehitaman, ukuran yang didapatkan: $3-18 \mathrm{~cm}$, nama lokal: kerang darah, kerang daguk. Hal ini sesuai dengan pernyataan Carpenter dan Niem (1998) yang menyatakan bahwa, karakteristik A. granosa memiliki cangkang sama dengan yang di temukan di perairan Bagan Siapi-api, yaitu tebal dan padat, sangat menggembung, ukuran panjang cangkang lebih besar dibanding tinggi dan sedikit tidak seimbang. Umbo sangat menonjol, area kardinal agak besar. Garis rusuk sekitar 18 (15 sampai 20) dengan adanya jarak antara garis rusuk.

Berdasarkan penelitian yang telah dilakukan dapat diketahui bahwa semua sampel kerang darah yang diperoleh termasuk ke dalam famili Arcidae dan Genus Anadara. Genus Anadara di Indonesia umumnya paling banyak dikonsumsi karena bernilai ekonomi dan merupakan salah satu sumber protein hewani. Jenis spesies yang diperoleh terdiri dari satu spesies yaitu Anadara granosa.

Berdasarkan hasil penelitian yang telah dilakukan secara morfologi perbedaan antara jantan dan betina sulit dibedakan. Adapun karakter morfologi yang berbeda antara kerang jantan dan betina antara lain adalah:

- Kerang jantan memiliki bentuk cangkang lebih kecil, panjang dan tipis sedangkan bentuk cangkang kerang betina besar, pendek dan tinggi.

- Kerang jantan memiliki garis rusuk sebanyak 18 garis sedangkan kerang betina sebanyak 20 garis rusuk.

Perbedaan antara kerang jantan dan betina juga dapat dilihat secara visual, yaitu dengan melihat dari warna gonadnya, kerang darah jantan diketahui dari gonad yang berwarna putih susu hingga putih krem, sedangkan yang kerang darah betina diketahui dari gonadnya yang berwarna oranye hingga kemerahan. Dapat dilihat pada Gambar 2.

Berdasarkan pengukuran morfometrik yang dilakukan terhadap kerang darah di peroleh nilai yang bervariasi. Berdasarkan Tabel 2 dapat diketahui bahwa ukuran karakter morfometrik panjang cangkang (PC) jantan lebih panjang dari pada betina. Kisaran panjang cangkang pada kerang darah jantan yaitu $23,96-50,52 \mathrm{~mm}$ dengan nilai rata-rata $32,18 \mathrm{~mm}$ sedangkan betina memiliki kisaran 23,89-38,61 mm dengan nilai rata-rata 31,19 mm. Nilai karakter morfometrik panjang cangkang kerang darah betina lebih rendah dari pada jantan diduga karena faktor lingkungan yang mempengaruhi pertumbuhannya. Hal ini sesuai dengan pernyataan Affandi et al. (1992) yang menyatakan bahwa faktor lingkungan juga mempunyai pengaruh terhadap pertumbuhan organisme, sehingga pada umur yang sama suatu spesies, ukuran mutlaknya dapat berbeda. Tinggi cangkang (TIC) pada kerang darah jantan mempunyai kisaran 18,45-29,48 mm dengan rata-rata 25,08 mm, sedangkan kisaran ukuran pada betina yaitu 19,09-38,61 mm dengan rata-rata 24,93 mm. Nilai karakter morfometrik tinggi cangkang (TIC) kerang darah jantan lebih rendah dari pada kerang betina diduga karena perbedaan umur antara 
kerang darah jantan dan betina. Hal ini sesuai dengan pendapat Strauss dan Bond dalam Guk (2017) yamg menyatakan bahwa, ciri morfometrik berubah secara kontinu sejalan dengan ukuran dan umur.

Karakter morfometrik, seperti panjang ligament (PL), tinggi umbo (TU), dan tebal cangkang (TEC) menunjukkan nilai karakter kerang darah jantan cenderung lebih besar dari pada betina. Hal ini ditunjukkan pada ukuran Panjang ligament (PL) kerang darah jantan mempunyai kisaran 18,55-28,01 mm dengan rata-rata 22,48 mm, sedangkan kisaran ukuran pada betina yaitu 16,43-27,41 $\mathrm{mm}$ dengan rata-rata 21,84 $\mathrm{mm}$. Tinggi umbo (TU) pada kerang darah jantan mempunyai kisaran 2,57-6,02 mm dengan rata-rata 4,37 mm, sedangkan kisaran ukuran pada betina yaitu 2,3-5,22 $\mathrm{mm}$ dengan rata-rata 3,86 $\mathrm{mm}$. Tebal cangkang (TEC) pada kerang darah jantan mempunyai kisaran 17,8-27,78 $\mathrm{mm}$ dengan rata-rata 23,86 $\mathrm{mm}$, sedangkan kisaran ukuran pada betina yaitu 10,57-27,21 $\mathrm{mm}$ dengan rata-rata $22,89 \mathrm{~mm}$.

Selain itu, bila dibandingkan antara berat total (BT) individu jantan dan betina, individu jantan lebih besar dari pada betina. Hal ini tampak pada kisaran berat total jantan berkisar 4,65$18,16 \mathrm{~g}$ dengan rata-rata 10,86 g, sedangkan betina memiliki kisaran 3,85-16,25 g dengan nilai rata-rata 10,42 g. Hasil ini sesuai dengan penelitian Arwin (2016) berat total kerang bulu (Anadara antiquata) jantan 5,78-54,98 g dan berat total betina 9.27-4,01 g. Nilai ini menunjukkan bahwa berat total kerang bulu jantan lebih besar dari pada betina. Nilai proporsi masing-masing karakter morfometrik dapat dilihat pada Lampiran 8 dan 9, sedangkan ukuran minimum dan maksimum setiap karakter morfometrik terhadap panjang cangkang (PC) dapat dilihat pada Tabel 3 .

Pada penelitian ini setiap karakter morfometrik kerang darah dihitung proporsinya terhadap panjang cangkang. Tabel 6 menunjukkan bahwa karakter morfometrik seperti tinggi cangkang (TIC), panjang ligament (PL) dan tinggi umbo (TU) tidak memiliki perbedaan, karena ratio perbandingan karakter morfometrik antara kerang darah jantan dan betina menunjukkan nilai yang sama. Sedangkan pada karakter morfometrik tebal cangkang (TEC) memiliki ratio perbandingan yang berbeda yaitu 1/7 pada kerang darah jantan dan 1/8 pada kerang darah betina, artinya karakter morfometrik tebal cangkang (TEC) kerang darah betina lebih panjang/besar ukurannya dari pada kerang darah jantan. Secara morfologi perbedaan ukuran kerang darah betina lebih panjang dibandingkan dengan kerang darah jantan. Hal ini sesuai dengan pendapat Ramesha dan Thippeswany (2009) yang menyatakan bahwa beberapa individu jantan dan betina memiliki ukuran lebar yang berbeda dan memiliki bentuk yang bervariasi. Lingkungan yang bervariasi dapat mempengaruhi bentuk cangkang bivalvia.

Untuk karakter morfometrik kerang darah jantan dan betina yang lain tidak terdapat perbedaan, karena ratio perbandingan karakter morfometrik yang lain antara kerang darah jantan dan betina menunjukkan nilai yang sama. Setiap karakter morfometrik kerang darah tersebut dilihat hubungannya dengan panjang cangkang (PC). Hubungan setiap karakter morfometrik dan panjang cangkang kerang darah dapat dilihat pada Gambar 3 (A-D).

Pada Gambar 3A, dapat dilihat bahwa karakter morfometrik tinggi cangkang (TIC) terhadap panjang cangkang (PC) kerang darah jantan dan betina memiliki perbedaan. Tinggi cangkang (TIC) kerang darah jantan dan betina mengalami peningkatan seiring pertambahan panjang cangkang (PC). Berdasarkan hubungan tersebut diperoleh nilai koefisien korelasi pada kerang darah jantan sebesar 0,46 dan 0,87 pada kerang darah betina. Artinya, hubungan tersebut berkorelasi sedang karena rentangnya $0,5-0,8$.

Pada Gambar 3B, karakter morfometrik panjang ligament (PL)

terhadap panjang cangkang (PC) kerang darah jantan dan betina memiliki perbedaan. Panjang ligament (PL) kerang darah jantan dan betina mengalami peningkatan seiring pertambahan panjang cangkang (PC). Berdasarkan hubungan tersebut diperoleh nilai koefisien korelasi pada kerang darah jantan sebesar 0,34 dan 0,88 pada kerang betina. Artinya, hubungan tersebut berkorelasi sedang karena rentangnya $0,5-0,8$. 
Pada Gambar 3C, karakter morfometrik tinggi umbo (TU) terhadap panjang cangkang (PC) kerang darah jantan dan betina hampir sama. Tinggi umbo (TU) kerang darah jantan dan betina mengalami peningkatan sejajar seiring pertambahan panjang cangkang (PC). Berdasarkan hubungan tersebut diperoleh nilai koefisien korelasi pada kerang darah jantan sebesar 0,13 dan 0,37 pada kerang betina. Artinya, hubungan tersebut berkorelasi lemah karena rentangnya $0-0,5$.

Pada Gambar 3D, karakter morfometrik tebal cangkang (TEC) terhadap panjang cangkang (PC) kerang darah jantan dan betina hampir sama. Tebal cangkang (TEC kerang darah jantan dan betina mengalami peningkatan sejajar seiring pertambahan panjang cangkang (PC). Berdasarkan hubungan tersebut diperoleh nilai koefisien korelasi pada kerang darah jantan sebesar 0,58 dan 0,65 pada kerang betina. Artinya, hubungan tersebut berkorelasi sedang karena rentangnya $0,5-0,8$.

Karakter tinggi cangkang (TIC), tinggi umbo (TU), tebal cangkang (TEC) dan panjang ligament (PL) adalah karakter-karakter yang mempunyai hubungan erat dengan karakter lain. Korelasi yang erat menunjukkan ukuran tubuh karakter lain dapat diwakili oleh salah satu dari karakter ini. Hal ini sesuai dengan pernyataan Dewi (2005) yang menyatakan bahwa peningkatan satuan suatu karakter akan diikuti oleh peningkatan satuan dari karakter yang lain.

\section{Pola Pertumbuhan Kerangn Darah (A. granosa)}

Berdasarkan panjang cangkang dan berat total kerang darah selama penelitian, diperoleh kisaran panjang cangkang 23,89-50,52 $\mathrm{mm}$ dan berat total 3,85-18,16 g. Untuk melihat hubungan panjang cangkang dengan berat total kerang darah dapat dilihat pada Gambar 4.

Hubungan panjang berat kerang darah di perairan Bagan Siapi-api menunjukkan nilai koefisien korelasi (r) untuk jantan yaitu 1,4674 dan betina 0,7441. Hasil tersebut menunjukkan bahwa terdapat keeratan antara panjang dengan berat sebesar 33,06\% untuk kerang jantan dan $8,33 \%$ untuk kerang betina (Gambar 7). Nilai $r$ menunjukkan bahwa keragaman yang dipengaruhi oleh faktor lain, kemungkinan cukup kecil (Walpole, 1995).

Berdasarkan Gambar 7, nilai b dari persamaan panjang berat untuk kerang darah jantan adalah 1,4674 dan untuk kerang darah betina 0,7441. Dimana nilai b yang didapatkan untuk kerang jantan dan betina lebih kecil dari 3 atau disebut juga allometrik negatif yang berarti pertambahan panjang lebih cepat dari pada pertambahan beratnya, dimana kerang darah memanfaatkan energinya untuk pertumbuhan panjangnya dibandingkan dengan pertumbuhan beratnya. Hal ini sesuai dengan pernyataan Suruwaky dan Gunaisah (2013) yang menyatakan bahwa pertambahan panjang yang lebih cepat dibandingkan berat bisa disebabkan oleh eksploitasi secara berlebihan melalui tangkapan sehingga mempengaruhi panjang-berat.

Hubungan panjang berat kerang darah di perairan Bagan Siapi-api menunjukkan nilai koefisien korelasi (r) untuk jantan yaitu 1,4674 dan betina 0,7441 . Hasil tersebut menunjukkan bahwa terdapat keeratan antara panjang dengan berat sebesar 33,06\% untuk kerang jantan dan $8,33 \%$ untuk kerang betina (Gambar 7). Nilai $\mathrm{r}$ menunjukkan bahwa keragaman yang dipengaruhi oleh faktor lain, kemungkinan cukup kecil (Walpole, 1995).

Berdasarkan Gambar 7, nilai b dari persamaan panjang berat untuk kerang darah jantan adalah 1,4674 dan untuk kerang darah betina 0,7441. Dimana nilai b yang didapatkan untuk kerang jantan dan betina lebih kecil dari 3 atau disebut juga allometrik negatif yang berarti pertambahan panjang lebih cepat dari pada pertambahan beratnya, dimana kerang darah memanfaatkan energinya untuk pertumbuhan panjangnya dibandingkan dengan pertumbuhan beratnya. Hal ini sesuai dengan pernyataan Suruwaky dan Gunaisah (2013) yang menyatakan bahwa pertambahan panjang yang lebih cepat dibandingkan berat bisa disebabkan oleh eksploitasi secara berlebihan melalui tangkapan sehingga mempengaruhi panjang-berat.

\section{Kondisi Habitat Kerang Darah (A. granosa)}

Parameter kualitas air yang mempengaruhi kehidupan Kerang darah diantaranya, adalah suhu, kecerahan, Salinitas, oksigen terlarut dan $\mathrm{pH}$. Parameter fisika dan kimia di perairan Bagan Siapi-api Kabupaten Rokan Hilir selama penelitian dapat dilihat pada Tabel 4. Berdasarkan hasil pengukuran kualitas air diketahui kisaran antara $30-31{ }^{\circ} \mathrm{C}$. Hasil ini masih 
dalam kisaran biota dasar (bentos). Suhu di perairan Bagan Siapi-api menunjukkan bahwa masih dalam toleransi suhu untuk kelangsungan hidup kerang darah. Berdasarkan penelitian Boonruang dan Janekarn pada Tahun 1983 di Phuket Thailand, kerang darah dapat ditemukan pada suhu 25-32,8 ${ }^{\circ}$ C. Salinitas di perairan Bagan Siapi-api mempunyai kisaran antara 26-27\%. Hal ini sesuai dengan pernyataan Widasari (2013) yang menyatakan bahwa, rata-rata salinitas sebesar 25-30 \% merupakan nilai salinitas yang sesuai dengan habitat kerang.

Berdasarkan hasil pengukuran yang diperolah selama penelitian, nilai kecerahan terendah pada saat surut berkisar $3 \mathrm{~cm}$. Tingkat kecerahan sangat dipengaruhi oleh kekeruhan perairan. Semakin tinggi kekeruhan perairan, maka akan semakin rendah penetrasi cahaya yang menembus air, sehingga tingkat kecerahan semakin rendah (Mujito et al., 1997). Derajat keasaman $(\mathrm{pH})$ di perairan Bagan Siapi-api mempunyai kisaran antara 6-7. Hal ini sesuai dengan pernyataan Hasri (2004) menyatakan bahwa derajat keasaman $(\mathrm{pH})$ yang dimiliki perairan laut senantiasa berada dalam keseimbangan karena perairan laut memiliki sistem penyangga (Buffer Capacity) yang mampu mempertahankan nilai $\mathrm{pH}$.

Kandungan oksigen terlarut di perairan Bagan Siapi-api mempunyai kisaran antara 4,42$5,41 \mathrm{mg} / \mathrm{l}$. Pada penelitian Setyobudiandi et al. (2004) diperairan Marunda ditemukan bahwa kerang lamis dapat ditemukan pada perairan yang memiliki kandungan oksigen 2,01-9,24 mg/l. Substrat dasar perairan sangat penting untuk kelangsungan hidup biota yang hidup di dasar perairan, substrat perairan sangat berperan penting untuk mencari makan, memijau ataupun bereproduksi. Berdasarkan dari hasil penyaringan (pengayakan) substrat dengan menggunakan saringan bertingkat didapatkan jenis substrat di perairan Bagan Siapi-api dapat dilihat pada Tabel 5. Berdasarkan pada Tabel 5 didapatkan 3 kelompok bagian besar, antara lain kerikil, lumpur dan pasir. Kemudian setelah dilakukan analisis substrat didapatkan persentase fraksi kerikil 10,53\%, persentase fraksi lumpur yaitu 31,05\%, dan untuk fraksi pasir yaitu 58,44\%, dengan demikian jenis substrat adalah berbentuk lumpur hingga pasir. Kondisi ini sesuai dengan kehidupan kerang darah yang menyukai substrat pasir berlumpur. Hal ini sesuai menurut Sari (2010) bahwa kerang darah banyak ditemukan pada lumpur halus atau kadang-kadang pasir berlumpur dan berlindung atau bersosiasi dengan mangrove di sebagian besar daerah tropis.

Gambar 2. Kerang Darah Jantan dan Betina (A. Granosa)
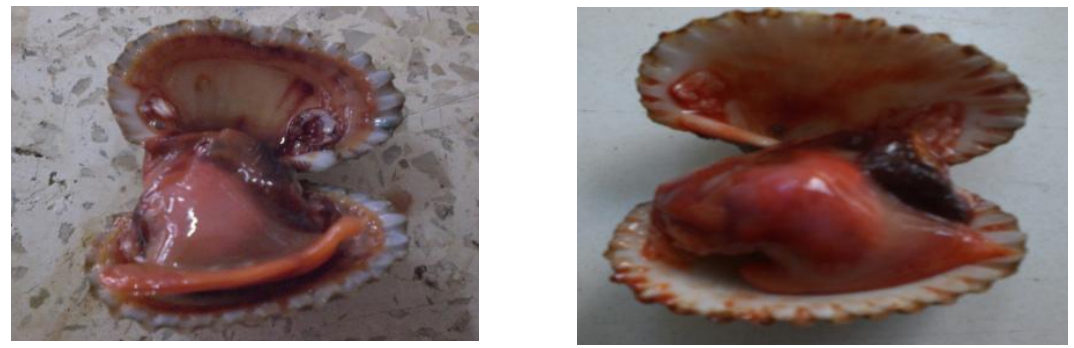

Table 2. Hasil Pengukuran Morfometrik Kerang Darah (A. granosa) yang diperoleh dari Perairan Bagan Siapi api (mm)

\begin{tabular}{lllclc}
\hline \multirow{2}{*}{ No } & \multicolumn{1}{c}{$\begin{array}{c}\text { Karakter } \\
\text { Morfometrik }\end{array}$} & \multicolumn{2}{c}{ Jantan } & \multicolumn{2}{c}{ Betina } \\
\cline { 3 - 6 } & & \multicolumn{1}{c}{ Kisaran } & $\begin{array}{c}\text { Rata- } \\
\text { rata }\end{array}$ & Kisaran & $\begin{array}{c}\text { Rata- } \\
\text { rata }\end{array}$ \\
\hline 1 & PC (Panjang Cangkang) & $23,96-50,52$ & 32,18 & $23,89-38,61$ & 31,19 \\
2 & TIC (Tinggi Cangkang) & $18,45-29,48$ & 25,08 & $19,09-28,91$ & 24,93 \\
3 & PL (Panjang Ligament) & $18,55-28,01$ & 22,48 & $16,43-27,41$ & 21,84 \\
4 & TU (Tinggi Umbo) & $2,57-6,02$ & 4,37 & $2,3-5,22$ & 3,86 \\
5 & TEC (Tebal Cangkang) & $17,8-27,78$ & 23,86 & $10,57-27,21$ & 22,89 \\
6 & BT (Berat Total) & $4,65-18,46$ & 10,86 & $3,85-16,25$ & 10,42 \\
\hline
\end{tabular}


Tabel 3. Proporsi Karakter Morfometrik terhadap Panjang Cangkang (PC)

\begin{tabular}{rlcccc}
\hline \multirow{2}{*}{ No } & \multicolumn{1}{c}{$\begin{array}{c}\text { Karakter } \\
\text { Morfometrik }\end{array}$} & \multicolumn{2}{c}{ Jantan } & \multicolumn{2}{c}{ Betina } \\
\cline { 3 - 6 } & & Rata-rata & Ratio & Rata-rata & Ratio \\
\hline 1 & TIC (Tinggi Cangkang) & 78 & $1 / 3$ & 80 & $1 / 3$ \\
2 & PL (Panjang Ligament) & 70 & $3 / 4$ & 70 & $3 / 4$ \\
3 & TU (Tinggi Umbo) & 14 & $3 / 4$ & 12 & $3 / 4$ \\
4 & TEC (Tebal Cangkang)* & 75 & $1 / 7$ & 74 & $1 / 8$ \\
\hline * = Karakter yang Berbeda & \multicolumn{4}{c}{}
\end{tabular}

Gambar 3A. Hubungan Tinggi Cangkang (TIC) terhadap Panjang Cangkang (PC)

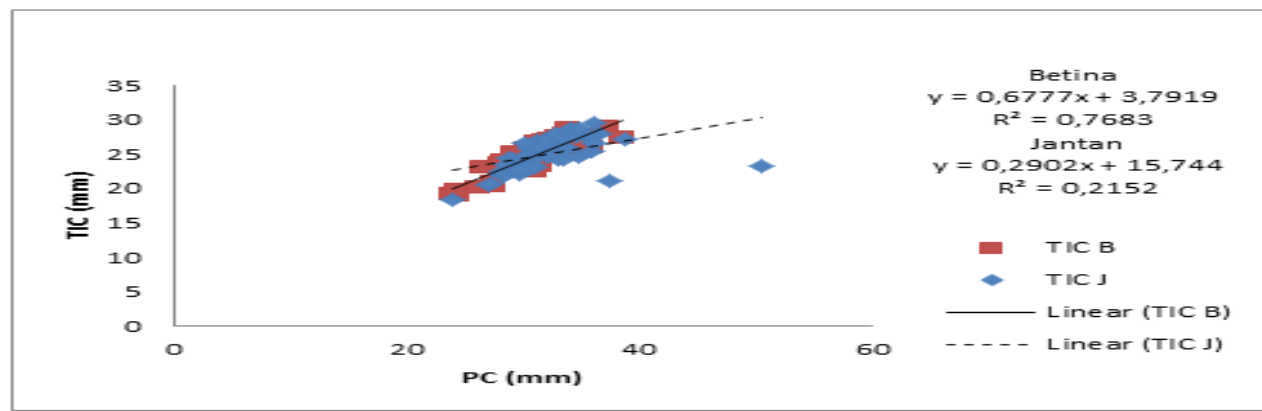

Gambar 3B. Hubungan Panjang Ligament (PL) terhadap Panjang Cangkang (PC)

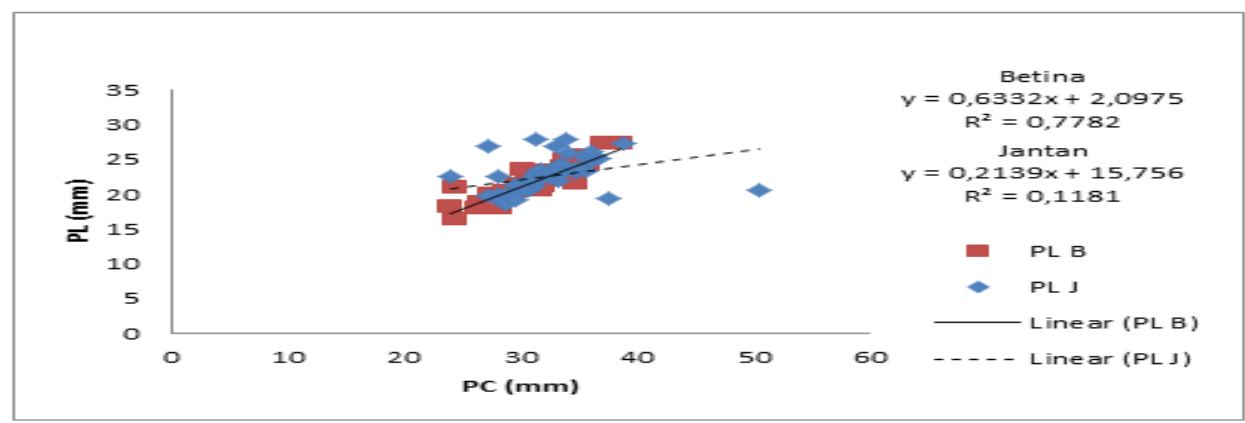

Gambar 3C. Hubungan Tinggi Umbo (TU) Terhadap Panjang Cangkang (Pc)

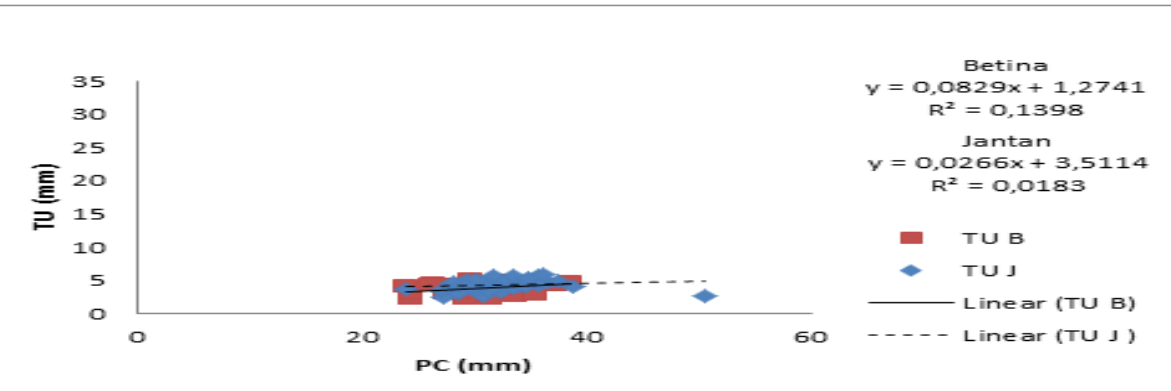

Gambar 4. Hubungan Tebal Cangkang (TEC) Terhadap Panjang Cangkang (PC)

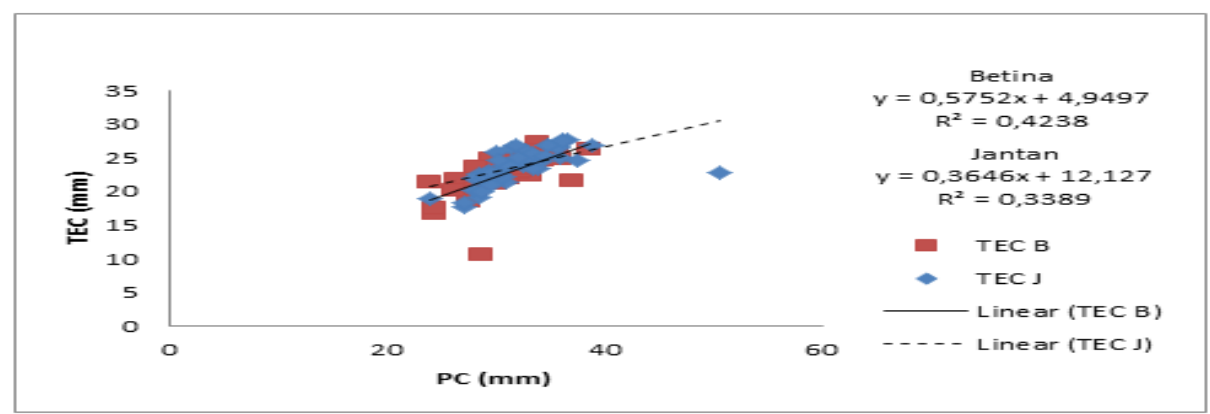


Gambar 5. Pola Pertumbuhan Berat Total (BT) terhadap Panjang Cangkang (PC)

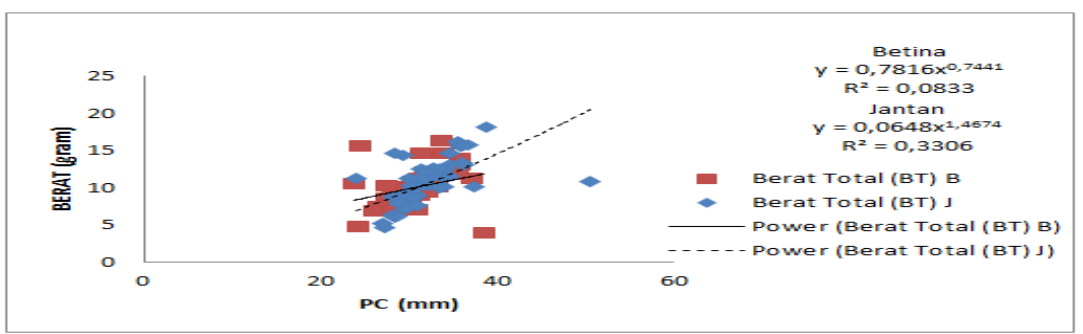

Tabel 4. Hasil Pengukuran Kualitas Air

\begin{tabular}{llcccc}
\hline \multirow{2}{*}{ No } & \multirow{2}{*}{ Parameter } & \multirow{2}{*}{ Satuan } & \multicolumn{3}{c}{ Titik Sampling } \\
\cline { 4 - 6 } & & ${ }^{\circ} \mathrm{C}$ & 31 & II & III \\
\hline 1 & Suhu & $\mathrm{Cm}$ & 5 & 30 & 31 \\
2 & Kecerahan & $\% \mathrm{o}$ & 27 & 26 & 3 \\
3 & Salinitas & - & 7 & 6 & 27 \\
4 & Derajat Keasaman $(\mathrm{pH})$ & $\mathrm{mg} / \mathrm{l}$ & 5,41 & 4,42 & 5,24 \\
5 & Oksigen Terlarut & &
\end{tabular}

Tabel 5. Jenis Substrat di Perairan Bagan Siapi-api

\begin{tabular}{|c|c|c|}
\hline No & Jenis Substrat & Persentase (\%) \\
\hline 1 & Kerikil & 10,53 \\
\hline 2 & Lumpur & 31,05 \\
\hline 3 & Pasir & 58,44 \\
\hline
\end{tabular}

\section{KESIMPULAN}

Kerang darah yang diidentifikasi dan diukur morfometriknya sebanyak 100 individu yang terdiri dari 55 individu kerang jantan dan 45 individu kerang betina. Kerang darah memiliki kisaran panjang cangkang 23.89-50,52 mm dan berat total 3,85-18,16 g. Hubungan dari 4 karakter morfometrik terhadap panjang cangkang kerang darah jantan maupun betina bervariasi, yaitu terdapat hubungan yang berkorelasi lemah dan sedang. Nilai b pada kerang darah jantan 1,46 dan pada kerang darah betina 0,74, Pola pertumbuhan kerang darah dalam penelitian ini menunjukkan hubungan allometrik negatif.

Berdasarkan hasil pengukuran kualitas air diperoleh suhu $28-30{ }^{\circ} \mathrm{C}$, salinitas $26-27 \%$, kecerahan $5 \mathrm{~cm}$, pH 6-7 dan oksigen terlarut 5,24-5,41 mg/l. Secara umum kualitas air diperairan tersebut masih mendukung untuk kehidupan organisme perairan, khususnya kerang darah. Substrat dasar perairan Bagan Siapi-api adalah pasir berlumpur.

Penelitian ini merupakan data awal tentang morfometrik dan pola pertumbuhan kerang darah di perairan Bagan Siapi-api Kabupaten Rokan Hilir Provinsi Riau dan masih diperlukan informasi aspek biologi yang lainnya seperti laju pertumbuhan, reproduksi, kajian komposisi kimia dan sebagainya.

\section{DAFTAR PUSTAKA}

Affandi, R., Safei, D. S. Rahardj, dan M. F. Sulistiono. 1992. Iktiologi: Suatu Pedoman Kerja Laboratorium. Departemen Pendidikan dan Kebudayaan. Direktorat Jenderal Pendidikan Tinggi. Pusat Antar Universitas. Ilmu Hayat. Bogor. Institut Pertanian Bogor. Bogor. 
Arwin. 2016. Pola Pertumbuhan dan Faktor Kondisi Kerang Bulu (A. antiquata) di Perairan Bungkoto Kota Kendari. Jurnal Manajemen Sumber Daya Perairan. 2(1): 89-100.

Carpenter, K. E. dan V. H. Niem. 1998. The Living Marine Resource of the Western Central Pacific Vol. 1. Seaweeds, Corals, Bivalves and Gastropods. Food and Agriculture Organization of the United Nations. Rome, Italy.

Guk, R. R. G. (2017). Pola Pertumbuhan Kepiting (P. purdus) di Rawa Desa Sawah Kabupaten Kampar Provinsi Riau. Skripsi. Fakultas Perikanan dan Kelautan. Universitas Riau.

Hasri, I. 2004. Kondisi, Potensi dan Pengembangan Sumber Daya Moluska dan Krustase pada Ekosistem Mangrove di Daerah Ulee Lheue Banda Aceh. Skripsi Sarjana. Fakultas Perikanan dan Ilmu Kelautan. Institut Pertanian Bogor. Bogor. 75 hal.

Latifah, A. 2011. Karakteristik Morfologi Kerang Darah (A. granosa). Departemen Teknologi Hasil Perairan, Fakultas Perikanan dan Ilmu Kelautan, Institut Pertanian Bogor. Bogor.

Ramesha M. M. dan Thippeswamy S. 2009. Allometry and Condition Index in the Freshwater Bivalve Parreysia corrugata (Muller) from River Kempuhole, India. Asian Fisheries Science. 4(22): 203-214.

Sari, S. N. 2010. Keragaman Morfometrik Kerang Darah (A. granosa) Diperairan Pesisir Banten. Skripsi. Departemen Manajemen Sumberdaya Perairan Fakultas Perikanan dan Ilmu Kelautan Institut Pertanian Bogor. Bogor. Hal 16-40.

Setyobudiandi, I., Soekendarsih E. Vitner Y. dan Setiawati R. 2004. Bio-Ecologi Kerang Lamis (Meretrix meretrix) di Perairan Marunda. Jurnal Ilmu-Ilmu Perairan dan Perikanan Indonesia. 11(1): 61-66.

Walpole, R. E. 1995. Pengantar Statistika Edisi Ke-3 alih Bahasa oleh Sumantri, B. PT. Gramedia Pustaka Utama. Jakarta. 515 hal. 